\title{
Druki tyczące spraw tajemnych w Polsce XVI-XVII wieku ${ }^{1}$
}

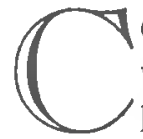

elem niniejszego artykułu jest przedstawienie problematyki wydawanego drukiem w Polsce w XVI i XVII w. piśmiennictwa z zakresu nauk tajemnych. Literatura ta, często niedoceniana (jak na przykład literatura astrologiczna, prognostyki i kalendarze, które do niedawna nie były uwzględniane w niektórych bibliografiach), stanowi niewątpliwie ważny element staropolskiej kultury. Niejedno przecież życie układane było na podstawie astrologicznych przepowiedni, niejedno odebrano w imię walki z nieprzyjaciółkami Boga i ludzi, wspólniczkami Szatana czarownicami, niejedno upłynęło w strachu przed piekłem i diabłami, niejedna wreszcie fortuna została stracona na złudne poszukiwania kamienia filozoficznego i sposobu produkowania złota. O wielkiej popularności tego typu literatury świadczą bardzo duże nakłady, jakie druki kalendarzowe osiaggały już w pierwszej połowie XVI w.

Literaturą, której poświęciłem tę pracę, zajmowali się już wcześniej Roman Bugaj², Janusz Goliński ${ }^{3}$, Jacek Sokolski ${ }^{4}$. Stosunkowo najwięcej uwagi poświęcono drukom kalendarzowym. Kazimierz Piekarski już w roku 1939 podjął próbę zarejestrowania wszystkich zachowanych polskich kalendarzy XV i XVI w. Niestety wybuch wojny udaremnił jego dzieło. Kalendarze drukowane uwzględnia w swojej Bibliografii Karol Estreicher. Notuje on jednak tylko część tejże literatury i jego wiadomości muszą być uzupełniane katalogami kalendarzy zachowanych w polskich księgozbiorach. Zainteresowanie literaturą kalendarzową zaczęło wzrastać dopiero w okresie powojennym. Po katalogach B. Górskiej ${ }^{5}$, K. Kłodzińskiej ${ }^{6}$ i M. Paterak ${ }^{7}$, w roku 1994 opublikowano dwa nowe zbiory: J. Buły oraz E. SteczekCzerniawskiej9. Ponadto w Instytucie Bibliotekoznawstwa i Informacji Naukowej Uniwersytetu Warszawskiego powstały dwie prace magisterskie, które tematycznie nawiązują do niniejszego artykułu: w roku 1981 Literatura magiczna $i$ astrologiczna $w$ Polsce w latach 1700-1764 Anny Gołąb (napisana pod kierownictwem profesor Barbary Bieńkowskiej) oraz w roku 1989 Polskie kalendarze drukowane 1474-1550 Danuty Głowackiej

Z Badań Nad Polskimi Księgozbioram Historycznymi

t. 21, Warszawa 2003. 
(pod kierownictwem docenta doktora habilitowanego Edwarda Potkowskiego).

Pierwsze wzmianki o badaniach alchemicznych w Polsce pochodzą z XIIIXV w. Wśród alchemików tego okresu przeważają duchowni. Liczniejsze i obszerniejsze informacje na temat alchemii w Polsce spotyka się dopiero w XVI w. Z tego stulecia zachowało się kilka traktatów alchemików polskich, które były bardzo cenione, wydawane i poszukiwane również za granicą.

Niestety, nie wszyscy polscy alchemicy zostawili po sobie drukowane dzieła. Większość z nich, rozproszona po kraju, prowadziła cichą zakonspirowaną pracę alchemiczną, a działalność ich nie zawsze zachowała się w ówczesnych aktach. Poza tym rękopisy często były wywożone za granicę. ${ }^{10}$ Rękopisy alchemiczne były zawsze bardzo poszukiwane i nieraz płacono za nie ogromne sumy, wobec czego często padały łupem złodziei. Tym można thumaczyć fakt, że mimo dużego zainteresowania alchemią w Polsce, obecnie w naszym kraju znajduje się bardzo mało traktatów tego rodzaju.

W Akademii Krakowskiej alchemia jako odrębny przedmiot nie była wykładana. Wskazuje na to fakt, iż wśród XV- i XVI-wiecznych rękopisów Biblioteki Jagiellońskiej nie ma ani jednego traktatu alchemicznego pióra któregoś z profesorów Uniwersytetu. Również w Liber Diligentiarum ani tytuły wykładów, ani nazwiska autorów komentowanych ex cathedra nie wskazują, by alchemia była przedmiotem wykładów ${ }^{11}$. Natomiast w dwóch rękopisach BJ znajdują się odpisy bulli Jana XXII Spondent quas non exhibent divitas pauperes alchimistae... z 1320 roku $^{12}$. Pierwotnie była ona skierowana przeciwko alchemikom-fałszerzom pieniędzy, z biegiem czasu jednak została zgeneralizowana, a zajmowanie się alchemią w XIV i XV w. było formalnie zakazane we wszelkich instytucjach będących pod bezpośrednim lub pośrednim nadzorem Kościoła.

Większość profesorów Uniwersytetu Krakowskiego studiowała na Zachodzie, głównie we Włoszech. Przyczyny tego zjawiska były dwojakie - obok chęci zdobywania wiedzy odgrywały tu pewną rolę względy finansowe, po prostu koszty studiów i uzyskania biretu doktorskiego były za granicą niższe. Na uniwersytecie w Rzymie można było, za stosowną opłata, w ciagu kilku tygodni uzyskać doktorat, który gdzie indziej trzeba było sobie wypracować długą i systematyczną pracą. ${ }^{13}$ Jest bardzo prawdopodobne, że przywożono đo Polski również znajomość alchemii (która na Zachodzie była wykładana, o czym mogą świadczyć choćby rękopisy zachowane w uniwersyteckich bibliotekach) i bardziej lub mniej bezpośrednio przekazywano ją studentom na wykładach. 
Biorąc pod uwagę zainteresowanie alchemią profesorów Uniwersytetu Krakowskiego na przełomie piętnastego i szesnastego wieku, a także treść - jak moglibyśmy dziś powiedzieć - przewodnika metodycznego Martina Steinpeissa ${ }^{14}$, można stwierdzić, że alchemia, która z początku mogła być tylko przemycana na innych wykładach, najprawdopodobniej z czasem była włączana (choć możetylko w szczupłym zakresie) w treść wykładów wyższych lat studiów lekarskich w Krakowie. Co zrozumiałe, nie mogło być mowy o wykładach alchemii spekulatywnej ani o możliwości uzyskania kamienia filozoficznego. Należy tu rozumieć wykład praktycznych umiejętności potrzebnych lekarzowi przy sporządzaniu leków, czyli to, co moglibyśmy nazwać początkami chemii, farmakologii czy ziołolecznictwem.

Pośrednim na to dowodem może być dysputa z 1562 r. pomiędzy Feliksem z Sierpca a Stanisławem Zawadzkim ${ }^{15}$. Pierwszy z nich, jako przedstawiciel starych poglądów, bronił alchemii i wiary w moc magiczną kamieni szlachetnych. Drugi natomiast, idąc za modnymi poglądami antyparacelsu sowskimi, negował wartość alchemii i cudownych leków w medycynie.

Powodów zainteresowania alchemią w XV i XVI w. było wiele. Jednym $\mathrm{z}$ nich była intensyfikacja poszukiwań górniczych oraz powstanie hut ołowiu, miedzi i żelaza. W pobliżu dzisiejszej Nowej Huty w XV w. istniała huta mieszczanina krakowskiego, Węgra z pochodzenia, Jana Turzona. Był on jednym z najbogatszych ludzi w ówczesnej Polsce. Plotka głosiła, że całą swoją fortunę zawdzięczał właśnie alchemii. W drugiej połowie XV w. w Krakowie działał znakomity probierca (czyli, jak powiedzielibyśmy dziś, analityk chemiczny) Kasper Ber (Beer). W swoim laboratorium na rogu Rynku i Brackiej wykształcił wielu uczniów. Był on także specjalistą od spraw górniczych i hutniczych. ${ }^{16}$

Istotne znaczenie dla wzrostu zainteresowań alchemią miała ustanowiona przez Zygmunta Starego w 1517 r. Komora Górnicza. Związana z nią była Camera Separatoria, w której dokonywano analiz chemicznych. Było to pierwsze państwowe laboratorium chemiczne w Polsce. Sporządzano w nim m. in. kwas azotowy, siarkowy, wodę królewska, oczyszczano siarkę, rtęć, antymon i ołów. ${ }^{17}$

Alchemia miała możnych protektorów w osobach królów Zygmunta Augusta, Stefana Batorego iZygmunta III, biskupa F. Krasińskiego, magnatów O. Łaskiego, M. Wolskiego i J. Mniszcha. Olbracht Łaski sprowadził do Polski angielskiego maga Johna Dee i jego medium Edwarda Kelley'a. Przebywali oni na dworach Batorego i cesarza Rudolfa II. Z pewnością kontakty personalne $\mathrm{z}$ dworem praskim również nie pozostały bez wpływu na zainteresowania alchemią w Polsce. 
Taki właśnie protektorat powodował, że niełatwo było $\mathrm{z}$ alchemią walczyć. W Polsce tylko raz postawiono w stan oskarżenia osobę zajmującą się praktykami alchemicznymi. W 1491 r. bakałarz Kasper, altarysta kościoła Marii Magdaleny w Poznaniu, stawał tamże przed sądem biskupim, pozwany przez instygatora i oskarżony o zajmowanie się alchemią oraz o palenie płynnego złota, do czego zresztą sam się przyznał. Proces trwał 15 lat. Znany jest jednak tylko epilog sprawy. Zakończyła się ona w 1506 r.; na mocy wyroku bakałarzowi Kasprowi zabroniono zajmowania się kunsztem alchemicznym, przy czym wyszczególniony został zakaz sporządzania płynów, w tym płynu oddzielającego złoto od srebra, czyli kwasu azotowego. ${ }^{18}$ Był to chyba ostatni w Polsce przypadek potępienia alchemii przez Kościół, stała się ona bowiem zbyt powszechna i miała zwolenników wśród wysoko postawionych osobistości, które trudno byłoby pozwać przed sąd.

Duży wpływ na rozbudzenie zainteresowań tą właśnie dziedziną wiedzy miał przyjazd do Polski Paracelsusa. Zyskał on u nas zarówno gorliwych zwolenników (np. Jerzy Joachim Retyk, Andrzej Dudycz, Aleksander Suchten), jak i równie gorliwych przeciwników. Na przykład Ustawa Aptekarska Gdańska z 1597 r. zabraniała w paragrafie 12 sporządzania i sprzedawania leków cyrulikom, alchemikom i paracelsystom. ${ }^{19}$

O tym, że alchemia była popularna w Polsce już w XV w. ${ }^{20}$ może świadczyć znana historia z r. 1463, kiedy to w klasztorze dominikanów krakowskich wybuchł pożar wywołany przez mnichów fabrykujących złoto. Wspomina o tym Długosz w swojej kronice. Pożar ten zniszczył klasztor i dużą część miasta. ${ }^{21}$

O rozpowszechnieniu alchemii w Polsce w okresie Odrodzenia może również świadczyć fakt, że wydawane wówczas kalendarze często zawierały obok prognoz pogody i horoskopów także rady astrologiczne dotyczące alchemii, na przykład kiedy rozpoczynać studia i eksperymenty alchemiczne, w jakim czasie nastawiać odwary ziół, zapalać piece i topić metale. ${ }^{22}$

Znaczne zainteresowanie i rozpowszechnienie alchemii w Polsce w XVI i XVII w. spowodowało reakcję różnych kręgów, m. in. duchowieństwa, które poczęło otwarcie występować przeciwko tej sztuce i jej zwolennikom. Walka z alchemią miała jednak u nas przebieg łagodny. Głosy krytyczne, jakie padały pod adresem alchemii, były w pewnym stopniu słuszne, gdyż dokonywano wielu oszustw alchemicznych, często na eksperymenty tracono całe fortuny (jak Olbracht Łaski), rozpowszechniło się fałszowanie monet i masowe niszczenie kruszców podczas doświadczeń. 
Jak pisze prof. Hubicki, alchemicy XVI i XVII w. stanowili dość zwartą grupę, utrzymując między sobą ścisły kontakt. Świadczy o tym obfita korespondencja alchemiczna tych czasów. ${ }^{23}$ Rzuca to dodatkowe światło na przedmiot moich badań. Można bowiem przypuszczać, iż dzięki temu nie potrzebowali oni kontaktować się ze sobą za pomocą druku. Poza tym, upowszechnienie wyników ich pracy (np. recept alchemicznych) nie leżało w interesie samych alchemików (analogicznie można to odnieść również do magów). Myślę więc, że badanie druków dotyczących, w mniejszym czy większym stopniu, sztuk hermetycznych - alchemii czy magii, da nam raczej obraz ich społecznego oddziaływania, bardziej lub mniej trafnej krytyki tych kunsztów, czy wreszcie w jakimś stopniu tego, co oni sami chcieli o sobie ujawnić, niż rzeczywisty stan ich badan i przekrój problemów, którymi się zajmowali.

Zebrany przeze mnie materiał drukowany jest niezwykle skromny. Fakt ten zdaje się potwierdzać mój powyższy wniosek, tym bardziej, że, jak wiemy, powstawało wiele rękopisów alchemicznych. Alchemicy więc nie widzieli potrzeby publikowania dla szerszej publiczności wyników swoich badań. Potwierdza to również sprzeciw, z jakim spotkał się Schröter podejmując się tłumaczenia i wydania Archidoxae... Paracelsusa ${ }^{24}$. W pewnym stopniu potrzeby polskich alchemików zaspokajane były drukami sprowadzanymi z zagranicy. Poza tym rozpowszechnianie wiadomości na temat alchemii miało być obłożone klątwą. Arnold de Villanova grozi apopleksją każdemu, kto ośmieliłby się je zdradzić, i pisze w swym Rosarium: „Qui revelat secretum artis maledicetur apoplexia”. Rajmund Lullus zaś straszył za to piekłem. ${ }^{25}$ Pisze o tym również M. Eliade: „Nakaz zachowania tajemnicy w opus alchymicum utrzymał się od końcowego okresu świata starożytnego aż do naszych czasów. Zreszta przekazywanie „tajników rzemiosła” drogą pisaną jest iluzją nowoczesnej historiografii.(...) [Zawsze] w decydującej chwili potrzebna jest pomoc mistrza, chociażby po to, żeby zweryfikować autentyczność doświadczenia." ${ }^{26}$ Trudno jest natomiast powiedzieć, jaki był stosunek XVI- i XVII-wiecznych alchemików do tych średniowiecznych klątw. Pewne rozprawy alchemiczne bez wątpienia były wydawane drukiem, jak choćby traktaty polskiego alchemika Michała Sędziwoja (niestety $\mathrm{z}$ wielką szkodą dla tego artykułu wydawane tylko za granica).

Warto zwrócić uwagę, iż nigdzie nie wspomina się, jakoby alchemicy działali w spółce $z$ diabłem. Nawet przeciwnik alchemii Stanisław Poklatecki nie podnosi tego argumentu. 
Najważniejszymi dziełami z zakresu alchemii wydanymi drukiem w Polsce były dzieła Paracelsusa Archidoxae... oraz De praeparationibus... opublikowane w Krakowie w 1569 r. przezAdama Schrötera. Obie księgi, choć ukazały się w Krakowie, opatrzone były przywilejem cesarskim Maksymiliana II, ponieważ przeznaczone były głównie na eksport do Rzeszy Niemieckiej. Były to chyba pierwsze drukowane w Polsce książki ze specjalnym przeznaczeniem na eksport. Ich druk finansował wojewoda sieradzki Olbracht Łaski. Być może w podzięce wojewodzie za pomoc w finansowaniu tego wydawnictwa, Schröter opublikował druczek In gratulatiorum Alberto a Lasco palatini siradiensi (Kraków, Łazarz Andrysowic, s. a.). W obu dziełach Paracelsusa alchemia pojmowana jest jako naturalna siła przyrody, dzięki której na przykład zwierzęta mogą zamieniać spożywany pokarm na energię życiową i budulec własnych ciał.

$\mathrm{Na}$ uwage zasługują wydawane w latach $1585-1590$ przez Annibala Roseliusa kolejne tomy Pymander Mercurii Trismegisti... Były to publikacje opatrzonych irenicznymi komentarzami hermetycznych tekstów mitycznego Hermesa Trismegistosa. Z tych właśnie względów dzieło to było dla autora podwójnie niebezpieczne. W tytułach komentarzy zwraca szczególnq̨ uwagę bardzo skrupulatne powoływanie się Rosselego na zwierzchności - biskupów i nuncjuszów apostolskich. Sprawiają one wrażenie, że autor z góry już chciał uprzedzić wszelkie ataki i oskarżenia o nieprawomyślność.

W XVII wieku ukazały się dwa alchemiczne apokryfy. Pierwszy, zatytułowany Ein aussfürlicher schöner..., Dantzigk 1681, przypisany został nigdy prawdopodobnie nie istniejącemu dominikaninowi Wincentemu Koffskiemu. Traktat miał ponoć zostać cudownie odnaleziony w krypcie jednego z gdańskich klasztorów dokładnie sto lat po śmierci autora (zm. 1488). Drugim apokryfem jest przypisany Albertowi Wielkiemu O sekretach bialoglowskich..., z fałszywym adresem wydawniczym Amszterdam ${ }^{27}, 1695$, 1698 (późniejsze wydania 1714(?), 1741, 1742). Słynnym średniowiecznym scholastykom (Albertowi czy też jego uczniowi św. Tomaszowi) dość często przypisywano autorstwo traktatów alchemicznych.

Pewne wiadomości „alchemickie" niejednokrotnie zawierały zielniki, jak wydany sumptem siostry Zygmunta III Anny Wazówny w 1613 r. w Krakowie Zielnik Herbarzem z ięzyka Lacinskiego... Szymona Syreniusza lub też Piotra Barcellina Quintae essentiae..., Kraków 1619.

Potępianiem praktyk alchemicznych zajmowali się: Stanisław z Gór Poklatecki (Pogrom Czarnoksięskie błędy, Latawcow zdrady, y Alchimickie fatsze..., Kraków 1595), ksiądz Fabian Birkowski w swoich Kazaniach 
na niedziele $i$ święta, Kraków 1628, a nawet Marcin Bielski w swojej Kronice... (Kraków 1564).

Największym ośrodkiem astrologicznym w Polsce w XVI w. był Kraków. Stało się tak za sprawą katedry astrologii na Uniwersytecie Krakowskim. Katedra astronomii na uniwersytecie istniała od ok. 1405 r. Była ona fundacją mieszczanina krakowskiego Jana Stobnera. Katedrę astrologii ufundował w połowie XV w. Marcin Król z Żurawicy. Przyczyniła się ona do rozsławienia krakowskiej szkoły astronomicznej prawie w całej Europie. Niestety, na początku XVI w. przechodziła ona okres stagnacji, czy nawet upadku. Jedną z przyczyn tego stanu, bodaj czy nie najważniejsza, było zbyt słabe uposażenie finansowe zajmujących tę katedrę profesorów. Dzieła odnowienia i zreformowania katedry podjął się Maciej z Miechowa. Chciał on zapobiec trudnościom finansowym przez dodatkowe uposażenie kolegiata, a także dokonać odnowienia od strony naukowej. Okres przeprowadzania tych reform trwał dość długo, rozpoczęto je w r. 1508, a zakończono ostatecznie w r. 1524. Jednym z postulatów Miechowity było, aby katedra obsadzana była dożywotnio lub choćby na co najmniej 15 lat. ${ }^{28}$ Postulat ten nie był zbyt rygorystycznie przestrzegany.

30 maja 1524 r. ówczesny rektor Jakub z Ercieszowa ogłosił ordynację katedry astrologii.

Aby nowe, dogodne warunki materialne, nie stały się przynętą dla osób niepowołanych, Maciej z Miechowa zastrzegł, że o pierwszeństwie w obsadzaniu katedry mają decydować wyłącznie naukowe kwalifikacje kandydata, czyli jego wiedza w zakresie nauk matematyczno-astronomicznych.Postanowiono, że wybrany profesor miał nią kierować przez piętnaście lat. Wybór najbardziej uzdolnionego w naukach astronomiczno-matematycznych magistra nauk wyzwolonych i umożliwienie mu specjalizacji w tej dziedzinie przez tak długi okres było odstępstwem od średniowiecznego ideału uniwersalnego uczonego i wyłomem ze skrupulatnie przestrzeganego prawa do awansu w hierarchii uniwersyteckiej na podstawie odbytego stażu.

Tak jak Marcin Król przy fundacji katedry astrologii, również Maciej z Miechowa przy jej reorganizacji sporządził dla niej odpowiedni program naukowy. Miał on być realizowany w ciagu czterech lat. $Z$ nich aż trzy przypadały na objaśnienie dzieł astrologicznych, a dopiero czwarty przeznaczono na wykłady o bardziej teoretycznej treści. W tym roku trzeba było czytać Almagest Ptolemeusza. Wykłady tego dzieła miały być uzupełnione przez objaśnianie dzieła Almagestum abbreviatum pseudo-Gebera, Epitome in Almagestum Ptholomaei Jana Regiomontana 
i komentarza Gebera do Almagestu. ${ }^{29}$ Żadne z tych dzieł nie ukazało się drukiem w interesującym nas tu okresie. Jedynie Jan z Głogowa w swoim Introductionem Compendiosum... powołuje się na Almagest. Jak pisze Crombie $^{30}$, Almagest w ogóle nie był drukowany do XVI w $-\mathrm{z}$ wyjątkiem streszczenia dokonanego przez Regiomontana.

Do najważniejszych obowiązków profesora zajmującego katedrę astrologii należało sporządzenie w ciagu roku trzech iudiciów. Jednym $\mathrm{z}$ nich miało być Maius iudicium anni, które trzeba było uzasadnić wieloma autorytetami naukowymi, racjami rozumowymi i danymi wynikającymi z doświadczenia. Dla Kolegium Większego profesor katedry astrologii miał opracować iudicium podające większe zaćmienia i informujące o mających się pojawić kometach. Było wskazane, aby kopię tego iudicium przesłać do ratusza krakowskiego dla członków magistratu. Spoczywał na nim także obowiązek sporządzenia jeszcze jednego prognostyku skróconego dla użytku szerszych kół.

Na szczególną uwagę zasługuje chyba wzmianka, że przytaczane w przepowiedniach argumenty miały mieć charakter matematycznoastrologiczny, tj. winny być zaczerpnięte $\mathrm{z}$ nauk wchodzących w skład quadrivium, szczególnie z geometrii, astronomii i optyki.

Realizacji tego programu naukowego miała służyć utwożona specjalnie dla katedry biblioteka. Maciej z Miechowa przeznaczył dla niej w zapisie część książek ze swoich zbiorów. Chociaż ta biblioteka fundacyjna składała się zaledwie z kilku rękopisów, w owych czasach, jak pisze M. Markowski ${ }^{31}$, była to wielka innowacja w organizacji pracy uniwersyteckiej.

Ostateczne zatwierdzenie urządzenia katedry astrologii nastapiło 15 listopada 1525 r. w dekrecie biskupa krakowskiego Piotra Tomickiego.

Ponieważ katedra astrologii odgrywała w XVI w. ogromną rolę w całym ruchu astrologicznym, wypadnie nieco więcej uwagi poświęcić jej profesorom. Najdłużej katedrę tę zajmowali Jakub z Iłży, Mikołaj z Szadka, Michał z Wiślicy, Andrzej Glaber z Kobylina i Piotr z Proboszczowic. ${ }^{32}$

Jakub z Iłży, zwany starszym, był uczniem Jana z Głogowa i Wojciecha z Brudzewa. Studia na Uniwersytecie Krakowskim rozpoczął w semestrze zimowym roku akademickiego 1489-1490. Na magistra nauk wyzwolonych został promowany około Nowego Roku 1495. W tymże roku podjął pracę dydaktyczną na Uniwersytecie. Katedrę astrologii zajmował w latach 1506-1515. W tym czasie publikował głośne Iudicia Cracoviensia. Miały one służyć nie tylko w Polsce, lecz także na Śląsku, na Węgrzech, w Czechach, Austrii, Saksonii, Prusach, a nawet w Moskwie. Na podsta- 
wie odziedziczonych po Wojciechu z Brudzewa notatek i w oparciu o własne obserwacje napisał w 1519 r. Opusculum aurei tractatuli in astrologicis de pluviis, ventis ac de aliis variis aurae dispositionibus, które uchodzi za jedno z pierwszych dzieł z zakresu klimatologii i meteorologii. Zmarł w sierpniu 1526 r. w drodze powrotnej z Rzymu.

Następcą Jakuba z Iłży był Mikołaj z Szadka (Prokopiades). Na krakowskim wydziale nauk wyzwolonych w 1508 r. został bakałarzem, a w $1512 \mathrm{r}$. magistrem. Jeszcze w półroczu letnim tego roku rozpoczałł wykłady na Uniwersytecie. W 1515 r. wszedł do Kolegium Mniejszego i objął katedrę astrologii. W tym właśnie roku wprowadzono w życie ustawę nakazująca, aby jeden profesor kierował katedrą przez lat piętnaście. Mikołaj z Szadka był pierwszym profesorem, który przez tyle właśnie lat spełniał te obowiazki. Ogłosił w tym czasie wiele prognostyków. Po opuszczeniu katedry zajął się teologia, nie zmienił jednak zainteresowań. Zmarł w $1565 \mathrm{r}$.

Po nim w 1531 r. katedrę objął Michał z Wiślicy. Studia rozpoczął w 1511 r. Bakałarzem został dopiero w 1521 r. Stopień magistra uzyskał. w 1524 r. Kierował katedrą tylko dziewięć i pół roku.

Pod koniec grudnia 1540 r. katedrę powierzono Andrzejowi Glaberowi (Łyskowi). Na Uniwersytet zapisał się on w r. 1518. Już w r. 1520 został bakałarzem, stopień magistra zdobył jednak dopiero w $1531 \mathrm{r}$.

Z prowadzonych na wydziale nauk wyzwolonych wykładów i ogłaszanych w tym czasie prognostyków wynika, że po Andrzeju Glaberze katedrę przejął Piotr z Proboszczowic. Magistrem został w 1541 r. Jeszcze przed objęciem katedry wykładał astrologię. Jego wielka sława jako astrologa-praktyka sprawiła, że z jego porad chętnie korzystał Zygmunt August. Kalendarze i iudicia Proboszczowica wydawane były w Krakowie w językach łacińskim, polskim i niemieckim. Zmarł nagle w czerwcu $1565 \mathrm{r}$.

Dydaktyczna i pisarska działalność profesorów zajmujących katedrę astrologii wykazuje, że przeprowadzona przez Miechowitę reforma osiagnę̧ła swój cel. W jej wyniku wzrosła znacznie liczba prowadzonych na Uniwersytecie wykładów astrologii i wydawanych prognostyków. Doprowadziło to do bujnego rozkwitu tej sztuki.

Wszelkiego rodzaju prognostyki, kalendarze astrologiczne, iudicia były literaturą bardzo pokupną, przynoszącą szybki, pewny i dość duży zysk. Adresowane były do różnych grup społecznych:

- szlachty zagrodowej i bogatych kmieci (którzy, jeśli sami nie potrafili czytać, mogli poprosić o odczytanie porad astrologicznych kogoś bardziej wykształconego ze swojego otoczenia), zawierały bowiem wiele informacji 
na temat zasiewów, zbiorów, pogody w ciagu roku czy hodowli zwierząt; - lekarzy - uważano wówczas za Platonem, że człowiek, czyli mikrokosmos, jest odpowiednikiem wszechświata, czyli makrokosmosu. Wszelkie zmiany w makrokosmosie miały wywierać przemożny wpływ na losy człowiecze. Słońce i każda z planet miały wpływać na ludzkie organy. Skuteczność działania leków i puszczania krwi były zależne od korzystnych koniunkcji i konfiguracji Zodiaku. W Średniowieczu lekarz przy badaniu chorego pilniej obserwował niebo niż pacjenta. ${ }^{33}$ Wykorzystywano więc astrologię przy diagnozowaniu i leczeniu chorób, puszczaniu krwi, stawianiu baniek itp.;

- kupców - z gwiazd przepowiadano ceny zbóż, urodzaje, dni dobre do handlu;

- kobiet - prognostyki zawierały wiele wiadomości dla „ciężarnych białych głów";

- alchemików-amatorów. Wykształceni lekarze i alchemicy sami zajmowali się układaniem iudiciów i horoskopów.

Zawierały też one informacje o przyszłości miast, ziem i krajów, narodów (na przykład Turków) i wojen.

Duża popularność i, co za tym idzie, dochodowość kalendarzy i prognostyków powodowała, że stawały się one przedmiotem nielegalnych przedruków i sporów między drukarzami. Jak się wydaje, przodował w tym dziele Hieronim Wietor. To on właśnie, nie zważając na to, iż w 1537 roku Maciej Scharffenberg otrzymał od króla dożywotni przywilej na druk kalendarzy i prognostyków ${ }^{34}$, wydał kalendarz na rok 1539. Scharffenberg wniósł skargę do sądu radzieckiego. Wyrok był dla niego pomyślny, Wietor miał oddać mu połowę nakładu, ale ten, nie przejmując się wyrokiem, dalej sprzedawał kalendarze, nie myśląc oddawać części wydrukowanych przez siebie kalendarzy. Wobec takiej ostentacji przeprowadzono u niego rewizję, ale Wietor zdążył wcześniej oddać wszystkie nie sprzedane dotąd egzemplarze autorowi ${ }^{35}$. Przebieg tej sprawy wskazuje, iż faktycznie starano się egzekwować prawa zagwarantowane królewskim przywilejem. Natomiast w 1539 r. Zygmunt I wydał dekret znoszący przywileje typografów i ustanawiający wolność druku ${ }^{36}$.

W $1528 \mathrm{r}$. Wietor wydał rubricellę ${ }^{37}$ krakowska, przeciwko czemu protestowała Unglerowa (rubricelle od połowy lat 20. XVI w. tłoczone były w drukarni Unglera). Po proteście wdowy do Wietora dołączyli inni drukarze. Na mocy wyroku rektorskiego Unglerowa miała wydawać połowę rubricelli na następny rok bądź też dojść do porozumienia z pozwanymi. Licznym sporom wywoływanym bezprawnymi przedrukami kalendarzy 
liturgicznych położył kres dopiero wyrok z 1622 r., w którym ustalono, że to biskup będzie decydował, kto ma je drukować. ${ }^{38}$

Dzięki dokumentom z procesów drukarzy dysponujemy dziś informacjami na temat wysokości nakładów druków kalendarzowych. Wietor w procesie z Scharffenbergiem został skazany na oddanie Maciejowi połowy wydanych przez siebie kalendarzy, którą obliczono na dziesięć tysięcy egzemplarzy o wartości $100 \mathrm{złp}^{39}$. Tak więc całkowity nakład miałby wynosić dwadzieścia tysięcy egzemplarzy ${ }^{40}$. Jest to liczba ogromna.

Jak łatwo obliczyć, cena jednego kalendarza wynosiłaby 0,3 grosza. Przyjmijmy, że cena 100 złp za 10000 egzemplarzy była sumą nieco zaokraglonąw dółprzezwymiarsprawiedliwości, wobecczegocenakalendarza dla odbiorcy detalicznego wynosiła pół grosza. Wacław Urban podzielił XVIwieczne książki na trzy grupy: tanie, tj. od pół grosza do 9 groszy, średnie od 10 do 29 groszy i drogie od 30 groszy (= 1 złp = 1 floren) i powyżej. ${ }^{41}$ Porównajmy te ceny z płacami: nauczyciele szkół parafialnych zarabiali w pierwszej połowie XVI w. średnio po 8 zł rocznie, pisarz miejski. w Warszawie otrzymywałrocznie około 50zł, organistaw Lublinie 16zł(1570), a zegarmistrz we Lwowie $24 z^{42}$. Można stwierdzić, że ceny kalendarzy nie stanowiły bariery mogącej ograniczać ich rozpowszechnianie, nawet wśród ludności mniejszych miasteczek i wsi.

W r. 1525, były czeladnik Unglera, Jan z Sącza, uzyskał przywilej na wyłączne prawo druku i sprzedaży krakowskiego kalendarza, pod warunkiem jednak, że do Wielkanocy 1526 r. uruchomi własny warsztat. Chcąc wydać kalendarz, a nie mając jeszcze przygotowanej własnej oficyny, zwrócił się do Wietora $\mathrm{z}$ prośbą o udostępnienie jego pras. Ten wyraził zgodę, ale widząc nie $w$ pełni zgodne $\mathrm{z}$ prawem postępowanie Sandeckiego podjał starania o ograniczenie jego monopolu. Doszło do procesu, w wyniku którego Sandecki dopuścił innych drukarzy i księgarzy do udziału w zyskach, oddając im na sprzedaż część - 3000 - egzemplarzy za 15 florenów. ${ }^{43}$

W Poznaniu aptekarz i rajca łęczycki Mikołaj w roku 1577 polecił Melchiorowi Neringowi druk 6000 egzemplarzy kalendarza ${ }^{44}$. Widocznie Mikołaj pewien był zysku ze sprzedaży kalendarzy wydanych własnym nakładem.

Dodajmy na marginesie, iż Hieronim Wietor nie ograniczał się bynajmniej do pirackich przedruków li-tylko kalendarzy. I tak na przykład dwanaście edycji zbioru Statutów Zygmunta I z 1. 1507-1521 w okresie od roku 1524 do 1550 niezmiennie nosiło date 1524 . Wietor obchodził w ten sposób przywilej, który opiewał tylko pierwsze wydanie. ${ }^{45}$ 
Almanachy i kalendarze drukowane były bądź to jako ścienne, tablicowe, w formacie plano, bądź też w formie kodeksowej, najczęściej w formacie $4^{\circ}$, choć dość często występują również formaty $8^{\circ}, 16^{\circ}$ lub $32^{\circ}$. Wydawnictwa astronomiczno-astrologiczne często ozdabiane były ilustracjami, mającymi charakter albo objaśniający, albo też zgoła sensacyjny, mający za zadanie zaciekawienie i zaintrygowanie czytelnika. Były to drzeworyty przedstawiające zaćmienia Słońca i Księżyca, ilustrujące, jakie planety odpowiadają jakim częściom ciała (Kalendarz na rok 1592 Jana Tenaciusa), czy też komety i złe skutki, jakie one powodują (Prognosticon Dawida Herliciusa z 1628 r.). Często spotyka się personifikacje planet. Występują one pod postaciami królów, biskupów, rycerzy, medyków bądź astronomów. Również często występują personifikacje astronomii, astrologii i medycyny. Są one przedstawiane w postaciach kobiet. Kalendarze zdobione były rysunkami tzw. prac rocznych. Przedstawiały one zajęcia, jakie wykonuje się w kolejnych miesiącach roku (na przykład siew, żniwa, orka, tłoczenie win).

Tytuły prognostyków są zazwyczaj standardowe. Najczęściej występują Prognostyk.., Almanach..., Rozsqdek..., Iudicium..., Przestroga.... Pewne "chwyty socjotechniczne" mające zachęcić do kupna, zastosowane są w kalendarzach Bernata Krakowczyka (na lata 1601, 1602, 1596), Wawrzyńca Swiczkowica (1619), Jana Tenaciusa (1592). Tytuły często przedstawiały treść publikacji (...Mars panem tego roku, Saturnus pomocznikiem. Dnia 9 kxięzicza Sticznia zaczmi szye miesziącz wssistek, w konczu stopnia kozoroscza, ktorego Moskwa..., Dzienne sprawy... Kaspra Goskiego 1562-1563). Umieszczane w tytułach wszelkie możliwe funkcje i tytuły naukowe autorów, a także zapewnienia, że prognostyk został ,z pilnością wyrachowany" i ,ku dobru pospolitemu do druku podany" miały zapewne za zadanie uwiarygodniać jego treść. Podobne funkcje spełniały prawdopodobnie, umieszczane w tytule lub na początku druku, przepowiednie dotyczące zaćmień, które astronomowi łatwo było wyliczyć, a które miały być sprawdzianem wiarygodności innych przepowiedni.

Pewna część prognostyków i kalendarzy wyposażona była w drukowane dedykacje. Jak wielka była to część ówczesnej produkcji nie sposób dziś określić ze względu na nieznajomość całości materiału. Mogę jedynie stwierdzić, iż spośród zebranych do celów tej pracy 483 druków typu astrologicznego drukowane dedykacje posiada 71 , czyli ok. 14,7\%. Kalendarze dedykowane bywały kasztelanom, wojewodom, biskupom, magnatom, możnej szlachcie. Adam Rozga zadedykował swój kalendarz 
na rok 1651 samej Matce Boskiej.

Dokładniejszą strukturę dedykacji przedstawia tabela:

\begin{tabular}{|c|c|r|}
\hline L.p. & Adresaci dedykacji & Ilość publikacji \\
\hline 1 & Biskupi & 7 \\
\hline 2 & Cesarz Rzymski Rudolf II & 1 \\
\hline 3 & Cześnicy & 2 \\
\hline 4 & Hrabiowie & 1 \\
\hline 5 & Kanclerzowie & 5 \\
\hline 6 & Kapituła płocka & 1 \\
\hline 7 & Kasztelanowie & 7 \\
\hline 8 & Książęta & 14 \\
\hline 9 & Księża & 1 \\
\hline 10 & Marszałkowie nadworni & 2 \\
\hline 11 & Matka Boska & 1 \\
\hline 12 & Miasto Lublin & 1 \\
\hline 13 & Podkomorzowie & 2 \\
\hline 14 & Podskarbiowie & 1 \\
\hline 15 & Sekretarz KJM & 1 \\
\hline 16 & Starostowie & 11 \\
\hline 17 & Stolnikowie & 1 \\
\hline 18 & Wojewodowie & 10 \\
\hline 19 & Zamożna szlachta & 1 \\
\hline 20 & Zygmunt III & 1 \\
\hline & & \\
\hline
\end{tabular}

Jak widać, autorzy prognostyków wybierając adresatów dedykacji kierowali się przeważnie względami pragmatycznymi. Utwory swoje przypisywali ludziom możnym, wysokim urzędnikom państwowym, co zapewne mogło im przynieść wymierne korzyści.

Autorzy układali swoje prognostyki z trzech powodów: urzędowo, jako profesorowie katedry astrologii lub astrologowie miejscy, z zamiłowania lub wprost dla pieniędzy. Przważnie związani byli z Uniwersytetem Krakowskim, ale nie było to regułą bez wyjątku.

W literaturze astrologicznej dominuje wyraźnie język polski. Łacina przeważa w pierwszym trzydziestoleciu XVI w., później jest wypiera- 
na przez polski. W w. XVII prognostyki publikowane są juź prawie tylko po polsku. Na użytek Polski drukowano też kalendarze w języku niemieckim, jest ich jednak niewiele. Drukowane były we Wrocławiu, Gdańsku i Szczecinie. Czasem publikowano ten sam prognostyk w różnych językach (np. Iudicium Cracoviense na rok 1535).

Język publikacji wyznacza krąg jej odbiorców. Jest oczywiste, że druki w języku polskim były dostępne szerokim kręgom czytelniczym. W tytułach prognostyków niejednokrotnie podkreślano, iż sąone publikowane w języku polskim, aby były dostępne dla szerszych kręgów (np. Przeyrzenie przygod swiatskich... Piotra z Proboszczowic, na rok 1544). Dokładne zestawienie języków druków astrologicznych przedstawiają poniższe tabele dla drugiej połowy XVI i XVII w.:

\begin{tabular}{|c|c|c|c|c|c|}
\hline \multirow{2}{*}{ Język } & \multicolumn{5}{|c|}{ XVI w. } \\
\cline { 2 - 6 } & VI & VII & VIII & IX & X \\
\hline Polski & 5 & 11 & 7 & 14 & 17 \\
\hline Lacina & 13 & 1 & - & 4 & 2 \\
\hline Niemiecki & 3 & - & 4 & 9 & 2 \\
\hline
\end{tabular}

\begin{tabular}{|c|c|c|c|c|c|c|c|c|c|c|}
\hline \multirow{2}{*}{ Język } & \multicolumn{10}{|c|}{ XVII w. } \\
\cline { 2 - 12 } & I & II & III & IV & V & VI & VII & VIII & IX & X \\
\hline Polski & 23 & 25 & 24 & 12 & 24 & 22 & 30 & 43 & 41 & 21 \\
\hline Lacina & 1 & 6 & 7 & 1 & - & 1 & - & - & - & 1 \\
\hline Niemiecki & 2 & - & 1 & 2 & - & - & - & - & - & - \\
\hline
\end{tabular}

Każdy wiek podzieliłem na dekady. ${ }^{46}$ Wyraźną przewagę języka polskiego widać zwłaszcza w 1. 60., 70. i 80. XVII w.

Książki astrologiczne drukowano w omawianym okresie przeważnie w Krakowie. Wiąże się to $\mathrm{z}$ pewnością z działalnością katedry astrologii na Uniwersytecie Krakowskim i jej profesorów. 


\begin{tabular}{|c|c|c|c|c|c|}
\hline \multirow{2}{*}{ Miasto } & \multicolumn{5}{|c|}{ XVI w. } \\
\cline { 2 - 6 } & VI & VII & VIII & IX & X \\
\hline Kraków & 20 & 6 & 5 & 6 & 7 \\
\hline Gdańsk & - & - & 3 & 5 & - \\
\hline Wrocław & - & 1 & 2 & 3 & 2 \\
\hline Poznań & - & - & - & 1 & - \\
\hline Lwów & - & - & - & - & 1 \\
\hline Lowicz & - & 1 & - & - & - \\
\hline Toruń & - & - & - & - & 1 \\
\hline
\end{tabular}

\begin{tabular}{|c|c|c|c|c|c|c|c|c|c|c|}
\hline \multirow{2}{*}{ Miasto } & \multicolumn{10}{|c|}{ XVII w. } \\
\cline { 2 - 12 } & I & II & III & IV & V & VI & VII & VIII & IX & X \\
\hline Kraków & 14 & 12 & 7 & 1 & 15 & 15 & 22 & 35 & 39 & 24 \\
\hline Gdańsk & 1 & - & 1 & 1 & - & 6 & 1 & - & - & - \\
\hline Wrocław & 1 & - & 1 & - & - & - & - & - & - & - \\
\hline Poznań & - & - & - & - & - & - & - & 1 & - & 1 \\
\hline Leszno & - & - & - & 1 & - & - & - & - & - & - \\
\hline Lwów & - & - & 1 & - & - & - & - & - & - & - \\
\hline Szczecin & - & 3 & 7 & - & - & - & - & - & - & - \\
\hline Wilno & 2 & - & - & - & - & - & - & - & - & - \\
\hline Lublin & - & - & - & 2 & - & - & - & - & - & - \\
\hline Zamość & - & - & - & - & - & - & - & 2 & 2 & - \\
\hline
\end{tabular}

Dane dotyczące miejsc druku pism astrologicznych są oczywiście z konieczności niepełne, ponieważ wiele druków nie ujawnia miasta publikacji. Prognostyki krakowskich profesorów, Iudicia cracoviense, często drukowano za granica, np. w Rzymie ${ }^{47}$, wobec czego, jeżeli miejsce druku nie jest znane lub choćby z dużą dozą prawdopodobieństwa możliwe do ustalenia, prognostyk taki pomijałem w tym zestawieniu, aby uniknąć błędu. Ograniczenie to jednak z pewnością nie zmienia proporcji miejsc wydania.

Prognostyki i kalendarze pełniły funkcję popularnego serwisu informacyjnego. Często zawierały one jakieś aktualne wiadomości polityczne. Przepowiadając jakieś wydarzenia społeczne, polityczne czy militarne, równocześnie informowały o sytuacji obecnej. Można się 
domyślać, że w prognostykach autorzy niejednokrotnie „przepowiadali” wydarzenia (takie jak np. wybuch wojny, ruchy wojsk, sytuacje polityczne czy „wyczytane z gwiazd” ceny zbóż), które człowiekowi wykształconemu, obytemu w świecie nietrudno było przewidzieć lub dowiedzieć się o nich" ${ }^{48}$. Dzięki temu informacje takie trafiały „pod strzechy”, gdzie inną drogą przypuszczalnie nie dotarłyby.

Kościół katolicki potępiał astrologię. Wiele zakazów dotyczących wróżbiarstwa znajduje się w Biblii (w księgach Zachariasza, Jeremiasza, Izajasza, Mądrości Syracha, 2 Ks. Kronik, Ks. Kapłańskiej, Ks. Powt. Prawa). O konieczności cenzurowania książek astrologicznych mówiono na synodach płockim (1593) i krakowskim (1601). ${ }^{49}$ Zakazywano ich na synodzie płockim (1593), warmińskim (1610 - tu potępiono także senniki) i luckim (1607). Ten ostatni ustalił, że duchowni mieli pouczyć wiernych, aby nie tylko nie czytali takich książek, ale także nie słuchali podobnych opowieści. Natomiast w zbiorze Tylickiego z 1608 r., w ustawach synodu diecezji krakowskiej z r. 1601 podkreślono, iż na druk iudiciów i minucji konieczna jest ocena i aprobata miejscowego biskupa lub jego deputatów, inaczej drukarz może zostać ukarany. ${ }^{50} \mathrm{M}$. in. właśnie książki dotyczące rzeczy przyszłych zostały potępione w 9. Regule Indexu ksiagg zakazanych (polskie wydania 1603, 1604, 1617). W statutach Konrada, biskupa wrocławskiego, spisanych na zwołanym przez niego synodzie w 1446 r., naznaczono czarnoksiężnikom czterdzieści dni pokuty, astrologowi zaś, qui videt in astrolabio futura, dwa lata. ${ }^{j 1}$ Zastanawia więc wielka ilość publikowanych bez przeszkód prognostyków, tym bardziej, że wiele z nich było dedykowanych biskupom (chyba nie bez ich zgody), kapitułom czy nawet Matce Boskiej. Co więcej, autorem jednego prognostyku był S. Ząmbkowic, tłumacz i wydawca polskiego Mtota na czarownice.

W 1586 r. w Krakowie wydana została bulla Syxtusa V przeciwko astrologom i od tego czasu wiele prognostyków zawiera w tytule zwrot „,według Bully Oyca Sw. Syxta V...”. Sądzę, iż miała to być formułka zapobiegająca ewentualnemu oskarżeniu o nieprawomyślność. Jak jednak można zauważyć, rachunek ekonomiczny wyraźnie bierze górę nad wszelkimi zakazami.

Należy pamiętać, że zachowane do dziś kalendarze astrologiczne i prognostyki stanowią z pewnością tylko czesść ówczesnej produkcji wydawniczej. Wiele $\mathrm{z}$ nich zaginęło bezpowrotnie, wiele zapewne czeka na odkrycie, wiele nie jest notowanych w bibliografiach. Literatura tego typu niejednokrotnie zachowała się tylko w zdefektowanych fragmentach, jako makulatura w oprawach innych książek. O jednym z takich prognostyków, zachowanym w oprawie jednej z ksiag dworu królewskiego (Rachun- 
ki Królewskie nr 112 z r. 1543), pisał Edward Potkowski ${ }^{52}$. Prognostyk ten zatytułowany był Iudicium Astrologicum ab Alberto de Sierpcz bonarum artium Baccalaureo, pro Anno Domini 1539 conscriptum, wydrukował go Hieronim Wietor w początku r. 1539. Był to jeden z tych kalendarzy, o które procesował się Wietor z Maciejem Scharffenbergiem. Egzemplarze Iudicium Astrologicum odnalezione w oprawie Rachunków Królewskich nie znalazły się nigdy w obiegu księgarskim - zachowały się bowiem w arkuszach drukarskich, nie rozcięte i nie złożone w książeczki. Nasza wiedza w tym zakresie jest więc z konieczności niepełna. Jednakże myślę, iż zebrany przeze mnie materiał pokazuje pewne zjawisko w kulturze staropolskiej.

ZXVI $^{53}$ i XVII wieku znane mi są 483 druki astrologiczne i wróżbiarskie. Obok licznych, publikowanch corocznie almanachów astrologicznych w grupie tej zwraca na siebie uwagę kilka wydawnictw typu podręcznikowego. Sa to Introductionum Astronomie in Ephemerides... oraz Tractatus preclarissimus in Judiciis Astrorum... Jana z Głogowa (1514), Introductorium Astrologie compendiosum..., którego autorem był Venceslaus Cracoviensis (1515), a zwłaszcza Usus Almanach seu Ephemeridum interpretatio De iudiciis erigendis 1532 . Był to jedyny w swoim rodzaju sensu stricto podręcznik dla układających i korzystających z almanachów. Jego autorem mógł być Michał z Wiślicy. Podkreślmy, że nie są znane drukowane podręczniki do nauki alchemii, magii czy ujarzmiania demonów.

Do końca XVI w. Polskę praktycznie omija nurt demonomanii. Jeszcze za panowania ostatnich Jagiellonów nie ma mowy o kultach szatańskich, popularnych skądinąd np. we Francji czy w Niemczech. Jest to tym dziwniejsze, że, jak pisze Jean Delumeau ${ }^{54}$, Renesans był epoką szczególnie nacechowaną strachem przed Szatanem i jego sztuczkami. Nie oznacza to jednak bynajmniej braku teologicznej demonologii. W roku 1420 prymas Mikołaj Trąba w swoim statucie wyklął „tych wszystkich, którzy dokonują czarów, wzywając diabła lub używając do tego rzeczy świętych." Synod łęczycki w 1512 r. nakazał duchownym zwalczanie czarów, guseł oraz wyjaśnianie z punktu widzenia nauki Kościoła problemu Szatana. ${ }^{55}$

Lęk przed diabłami począł przybierać na sile pod koniec w. XVI, w dobie kontrreformacji, osiągając apogeum w czasach rozprzężenia saskiego. Złożyło się na to wiele przyczyn - załamanie polityczne i gospodarcze, wojny „luterskie” ze Szwedami, zagrożenie tureckie, zwycięstwo kontrreformacji, koncepcja ,przedmurza chrześcijaństwa”. Wszystko to powodowało wzrost fanatyzmu religijnego, nietolerancji, dewocyjności, stworzenie schematu tzw. prawdziwego Polaka-katolika, a zarazem odrzucenie wszystkiego, co obce, 
niekatolickie. Heretyk stał się figura diaboli. Był personifikacją zła, które objawiało się w niszczeniu wizerunków świętych, zamienianiu kościołów na zbory. ${ }^{56}$

Reformatorzy, podırzymując wiarę w Szatana, zabronili używać przeciwko niemu systemu magii religijnej, a więc symbolu krzyża, skrapiania wodą święconą, modlitw. Musiało to pogłębić frustrację ludzi, w których z jednej strony utwierdzało się przekonanie o prawdziwości istnienia złych sit, a z drugiej odbierano im dawną, uświęconą tradycją, skuteczną przeciw nim broń. Reformatorzy twierdzili również, iż to właśnie papież jest oczekiwanym antychrystem, za co sami umieszczani byli przez katolików, na licznych drzeworytach i w utworach literackich, w czeluściach piekielnych. Od XVI w. Lutra utożsamiano z apokaliptyczną bestią. Mikołaj Rej, kalwin, umieścił w piekle całą katolicką hierarchię duchowną - poczynając od papieża, a kończąc na przedstawicielach licznych zgromadzeń zakonnych. ${ }^{57}$

Innym specyficznie polskim zjawiskiem było używanie tego typu argumentów dla celów politycznych. Ludy wschodu utożsamiane były w Europie z ludami apokaliptycznymi, których pojawienie się zapowiadać miało koniec świata, już od r. 1241-1242, czyli od inwazji mongolskiej. ${ }^{58}$ Podobne wyobrażenia utrzymywały się w Polsce jeszcze w XVII w. Turków pomawiano, iż w bitwie pod Cecorą dwukrotnie pokonali nasze wojska dzięki czarom. ${ }^{59}$

Cały ten ferment przyczyniał się do większego zainteresowania diabłami, piekłem i jego geografia, a także do coraz obszerniejszego rozbudowywania systemów demonologicznych.

Mimo to nie znalazłem polskich druków ściśle demonologicznych, nie wspominając nawet o satanistycznych, które opisywałyby piekło i jego mieszkańców na wzór np. De natura daemonum G. L. Anania, Demonology Jakuba I, króla Anglii i Szkocji czy Pseudomonarchia daemonum J. Wiera. Nie było tego typu druków rodzimych, nie dokonywano też przedruków. Szatan wyziera głównie z drukowanych polemik między katolikami a innowiercami, Żywotów świętych P. Skargi, rozważań na temat czterech ostatecznych rzeczy, jakie spotykają człowieka, bądź też z kart dzieł literackich, jak Wizerunek.. Reja. Wizerunek diabła wykorzystywany był więc $w$ trzech umownie wyodrębnionych przez mnie grupach książek: w literaturze pięknej, teologicznej (kaznodziejskiej) i ,polemikach religijnych”. Najszerszy krąg odbiorców miała zapewne literatura kaznodziejska. Trafiała ona bowiem nie tylko do czytelnika, który zapoznawał się z nią bezpo- 
średnio, ale również poprzez kazania do większej grupy, niepiśmiennych często, słuchaczy.

Wiele miejsca opisom piekła poświęcały dzieła dotyczące czterech ostatecznych rzeczy człowieka. Opisy wieczności piekielnej - w ujęciu teologicznym - wydawane były również samodzielnie. Diabeł trafiał do literatury religijnej. Postaci diabłów pojawiały się również w opisach Sądu ostatecznego, były one tam jednak postaciami drugoplanowymi, ich rola generalnie ograniczona była do zaganiania stada dusz potępionych do czeluści piekielnych. Wobec zmarginalizowania postaci diabła i ograniczenia jego roli do działań jedynie porządkowych, opisy takie nie są tutaj uwzględniane. ${ }^{60}$

Oddzielnym zagadnieniem jest Biblia (pierwsze wydanie 1511), która, chociaż sama niewiele miejsca poświęca diabłu, to jednak stała się fundamentem, na którym został zbudowany system chrześcijańskiej demonologii.

Wyobrażenia piekielne szerzone były trzema drogami: w kręgach wykształconych za pomocą literatury, zaś mniej wykształceni zapoznawali się z nimi przez ikonografię i słowo mówione. Diabeł i piekło były przedmiotami wielu kazań. Można więc stwierdzić, że w znakomitej większości drukowanych zbiorów kazań znajdowały się traktujące o nich fragmenty.

Sądzę więc, iż można pokusić się o konkluzję, iż w kulturze staropolskiej nie istniał w zasadzie nurt satanistyczny. W kulturze ludowej diabeł uważany był za istotę w pewnym sensie równą człowiekowi (o czym niżej) i nie powstawały w niej chyba pomysły równania go z Bogiem. Kultura szlachecka natomiast uznając realne istnienie „Szatana teologów” traktowała go jako wroga Boga i ludzi. Można to wyczuć np. w Pamiętnikach Paska. Wygląda więc na to, że jedynie teologowie, z niemałym trudem, budowali, szerzyli i podtrzymywali wiarę w Szatana. Diabeł był wielce poręczną bronią w walce - dla jednych z katolikami, dla innych z protestantami czy Żydami. Jednak, jak pisze Jacek Sokolski, , chociaż w dawnej literaturze polskiej pojawia się wiele postaci szatanów, trudno na tej podstawie wnioskować o istnieniu jakiegoś utrwalonego systemu poglądów demonologicznych." 61

Zdaniem folklorystów od XVI w. polski diabeł przyjmuje formę groteskową, a liczne opowieści ludowe sugerują iż diabeł rozumem ustępuje chłopu. Opowiadań o groźnym diable czyhającym na człowieka jest mało. W kulturze ludowej doby staropolskiej istniało przekonanie, że diabła można pokonać kijem lub sprytem. ${ }^{62} \mathrm{~W}$ pojęciu ludowym diabeł to 
raczej butny szlachetka, hulający - jak np. Boruta - po bagnach, niż groźny władca piekła i mocodawca czarownic. Zarzut konszachtów z diabłem był w tym wieku niesłychanie rzadki, a wyobrażenie o nim nader słabe. W porównaniu z czarownicą wydawał się on być postacią wręcz komiczną. Ogólnie znajomość demonologii w XVI-wiecznej Polsce była nikła. ${ }^{63}$ Jak pisze S. Bylina, w źródłach procesowych kościelnych i świeckich w XV i XVI w. diabeł był postacią ukazującą się rzadko, a i to zaledwie na drugim planie. Niekiedy spotyka się banalne sformułowania o działaniu za jego namową, nie pociagające za sobą istotnych konsekwencji. Nie posługiwano się oskarżeniami o zawarcie paktu z Szatanem. Można tłumaczyć to z jednej strony nikłą bardzo elitarną znajomością literatury demonologicznej, z drugiej zaś specyfiką popularnych wyobrażeń diabła mniej groźnych i przerażających niż na zachodzie Europy. ${ }^{64}$

Jak pisze B. Baranowski ${ }^{65}$, diabeł w zeznaniach czarownic pojawia się dopiero w II połowie XVI w. Najczęściej jest to diabeł szlachecki (w polskim szlacheckim stroju, często nosił herbowe nazwisko), niemiecki (od polskiego różnił się tylko strojem, spopularyzował się dopiero pod koniec XVIII w.) i tzw. „chowaniec”, który najczęściej występował na terenach wschodnich. Było to pogańskie bóstwo ,podniesione do piekielnych godności”. Natomiast tak bardzo spopularyzowany przez literaturę typ diabła, jaki spotkać można w Wizerunku... Reja, Postępku prawa czartowskiego... czy też Sejmie piekielnym... zupełnie nie jest spotykany w zeznaniach czarownic. Bezsprzecznie literatura piękna oddziaływała pośrednio na niepiśmienne masy, ale jej wpływ ograniczany był świadomością tradycji ludowej.

Mieszkańcy piekieł - tak jak mieszkańcy niebios i każdego państwa ziemskiego - mieli swoją hierarchię. Na sabatach (które opisywały na torturach „czarownice”) pojawiały się na przykład niższe kategorie diabłów, często była to „młódź piekielna” - czyli „diabełki”, które przygotowywały zabawę, roznosiły potrawy i napoje, zajmowały się posługami. Z rzadka tylko na sabat trafiał mężczyzna. Czasem pojawiał się tam np. mąż czarownicy, który, podobnie jak ,diabełki”, pełnił tylko funkcje pomocnicze. Z drugiej strony wiare $w$ istnienie takiej hierarchii prezentują uczone traktaty - polemiki religijne i rozprawy teologiczne (por. Postępek prawa czartowskiego 1570, List czartowski... W. Rościszewskiego 1609, Seym piekielny... 1615). Ponadto bardzo często w literaturze występuje Lucyfer przedstawiany jako władca piekła.

Z zebranego przeze mnie materiału wynika, iż na literaturę o treści piekielnej istniał spory popyt (por. np. Okazanie Antychrysta... M. Serwe- 
ta, b. r. Jest to przetłumaczony fragment V części dzieła pod tytułem Restitutio Christianismi. Przypuszczam, iż był to druk przeznaczony dla użytku popularnego. Może na to wskazywać jego niewielka objętość, jak również to, iż jest to przetłumaczony na język polski wyjątek z większego dzieła. Można również przypuszczać, że na druki tego typu istniał popyt, skoro wyjęto i przethumaczono taki właśnie fragment $z$ większej całości). Mimo to druków tej treści zachowało się niewiele - a może nie mimo, a właśnie dlatego. Niewątpliwie publikacji tego typu, o niewielkiej objętości, musiało być dość dużo, jednak ze względu na swój popularny charakter uległy zaczytaniu, rozproszeniu, zagubieniu lub celowemu zniszczeniu. ${ }^{66}$ Adresowane one były do specyficznej, mniej wyrobionej publiczności, która raczej nie gromadziła własnych księgozbiorów, co również nie sprzyjało ich zachowaniu.

Jedyne dwa druki ulotne dotyczące interwencji diabelskiej znam tylko $z$ opisu Juliana Tuwima ${ }^{67}$. Miały one pochodzić $z$ lat 1632 i 1641 . Jeden $\mathrm{z}$ nich jest tłumaczeniem $\mathrm{z}$ włoskiego.

Brak jest tu opisów opętań i egzorcyzmów. W czasach, kiedy powszechny był strach przed czarownicami, które potrafiły ,zadawać diabła”, jak również przed samymi diabłami, opisy takie z pewnością zyskałyby poczytność.

W tej grupie szczególne zainteresowanie budzą dwa druki: Postępek Prawa Czartowskiego przeciw narodowi ludzkiemu, Brześć Litewski 1570 oraz Seym piekielny, ok. 1615 (dalsze wydania: 1622 - dwie edycje, 1628, 1650 - trzy edycje). Są to satyry obyczajowe, w których wydarzenia rozgrywają się w zaświatach. W Postępku... znajdujemy pierwsze w Polsce opisy demonologiczne. W pismach kaznodziejskich, religijnych przeznaczonych dla szerszej publiczności, niejednokrotnie znajdują się fragmenty bądź całe rozdziały poświęcone diabłom i piekłu. Wymieńmy tu Jeana de Cartheny $O$ czterech ostatecznych rzeczach księgi czwory..., Kraków 1562, Pawła Gilowskiego Wykład Katechizmu Kościola Krześcijańskiego..., Kraków 1579, Piotra Skargi Żywoty Swiętych..., Wilno 1579, (kolejne wydania Kraków 1585, 1598, 1601, 1603, 1610, 1612, 1615, 1619, 1626, 1644), Franciszka Costera O czterech końcach ostatnich żywota ludzkiego..., Kraków 1606, różnego rodzaju Historie o zmartwychwstaniu Pańskim itp. Motywy piekielne wykorzystywane były w literaturze pięknej, jak na przykład przez Marcina Bielskiego w Kronice..., Kraków 1564, Mikołaja Reja w Wizerunku..., pierwsze wydanie Kraków 1558, Torquato Tasso Goffred Abo lervzalem Wyzwolona..., Kraków 1618, Jana Borawskiego Appellicius Ceramuboleus sive Theatrum Diabolorum..., Dantisci 1621, Łuka- 
sza Górnickiego Daemon Socratis albo rozmowa zlodzieja z czartem, 1624. To ostatnie dziełko jest przypowieścią dydaktyczna, w której czart daje złodziejowi naukę moralną. Transfiguracjami szatańskimi posługiwali się również w swoich pismach polemiści religijni: Marcin Łaszcz Okulary wtore na ciemne y slepe oczy ministrów... Przydana iest disputacia, którq miat Luter z dyabtem, 1605, tegoż autora Missio abo Postanie Lutra y Zwingla pierwszych Kacermistrzow, od Diabla z piekla..., Kraków 1609, Wojciech Rościszewski List czartowski Do Superintendentow y Ministrow Ewangelismu Luterańskiego, 1609, Marcin z Klecka Zwierciadlo saskie albo Magdeburskie..., Poznań 1610, Kasper Melcher Miaskowski Zbiór rythmów..., Kraków 1610, Mikołaj Cichowski Nowe zawstydzenie Socinistow..., 1654, tenże Wyklęcie Ministrow Arrianskich..., Kraków 1654, tenże Pogrom Diabla Arrianskiego..., Kraków 1659. Odpowiedziami na te ataki były dwa druki (jedyne jakie znalazłem) autorstwa Jonasza Schlichtynga Cichowiusza diabel zaklęty... oraz $X$. Cichovius Jezuita Diabla zaklętego odklać nie może, oba niedatowane. Przewaga strony katolickiej jest przytłaczająca. Polemiki religijne stanowią najliczniejszą grupę druków demonicznych, choć pojawiają się one dopiero w XVII wieku.

W zebranej literaturze tyczącej magii przeważają dzieła rozważające problem czarownictwa $\mathrm{z}$ punktu widzenia prawa. Są to bądź instrukcje dla prowadzących procesy o czary, bądź np. dzieła mniej lub bardziej odważnie i bezpośrednio biorące w obronę kobiety oskarżane o czarownictwo. Wszelkie wystapienia przeciw procesom czarownic dotyczyły tylko nadużyć i nieludzkich szczegółów, nie kwestionowały natomiast samej zasady ${ }^{68}$ (wyjątkiem był tu tylko Krzysztof Opaliński, który domagał się, by palono raczej tych, którzy czarownice skazują na stos). Niemalże wszyscy autorzy potępiali zbrodnię czarownictwa. Nie znalazłem natomiast ani jednego druku (i raczej nie należało się tego w ogóle spodziewać), który byłby dziełem czarownicy bądź czarnoksiężnika (np. podręcznika czarnej magii). Czarownicami na ogół były wiejskie kobiety, zajmujące się zielarstwem czy urokami. Kobiety te były niewykształcone, niepiśmienne, i nie tworzyły literatury, nie zapisywały nawet recept i zaklęć ani rezultatów swoich działań. Rola pisma w ludowych zabiegach magicznych była raczej niewielka. Tylko sporadycznie można spotkać się z bliżej nieokreślonymi znakami magicznymi - na przykład w jakimś małym miasteczku miała je wycinać żona karczmarza na drzwiach domu miejscowego proboszcza. Wynikało to $\mathrm{z}$ jednej strony $\mathrm{z}$ rzadkiej umiejętności pisania wśród prostych ludzi praktykujących zabiegi magiczne, $\mathrm{z}$ drugiej zaś z tradycyjności technik 
i rytuałów sięgających swą genezą kultury przedpiśmiennej. Ludowa magia i czary funkcjonowały przede wszystkim w kulturze gestu i słowa mówionego, jednym zaś z podstawowych warunków ich uprawiania była znajomość odpowiednich formuł magicznych zaklęć, w których nie wolno było niczego opuścić ani niczego zmienić. ${ }^{69}$ Inaczej ma się sprawa z tzw. magią uczoną. Magowie pisali traktaty i podręczniki magiczne. Księgi służyły również magom do zaklinania demonów. Benvenuto Cellini opisuje obrzęd wywoływania demonów w Koloseum, dokonywany przez maga - księdza. Cellini pisze: „Gdy czarnoksiężnik odprawił resztę swych obrzędów, zrzucił płaszcz czarnoksięski i zabrał stos ksiąg, które przyniósł ze sobą”. I niżej: „Namawiał mnie (tenże ksiądz - czarnoksiężnik), bym z nim wywoływał diabłów z zaczarowanej książki, przez co zdobędziemy nieskończone bogactwa, których zażądamy od nich (...)" ${ }^{70}$

Kurt Baschwitz pisze, iż księga magiczna używana przy zaklinaniu duchów ma inny charakter niż kompendia magii. Nie służy ona do nauczania magii, lecz sama jest instrumentem czarodziejskim, który ma władzę nad duchami. Karty księgi zapisane są i malowane ręcznie (!). Treść jej dotyczy ducha, który zobowiązuje się pod przysięgą być posłusznym magowi. Omawia również planety mające związek z owym duchem itp. rzeczy.

Aby poświęcić taką księgę, należało w jasną gwiaździstą bezwietrzną noc położyć księgę na rozstaju dróg, zakreślić wokół niej koło, po czym głośno wywoływać ducha, by się pojawił i zaprzysiagł posłuszeństwo na księgę.

Księga zawiera też formuły odpędzające upartego demona.

Czarodziejską księgę należy zaopatrzyć w zamek i trzymać zamknięta, ponieważ gdyby otworzył ją ktoś niepowołany, mogłoby to mieć fatalne skutki. $^{71}$

Można więc zaryzykować stwierdzenie, iż książek tego typu nie drukowano w ogóle. Jest oczywiste, że dostęp do nich musiał być ograniczony. Nie mogły one dostać się w niepowołane ręce, co mogłoby spowodować jakieś nieszczęście. Nie była to literatura, którą można by swobodnie wprowadzić na rynek. Gdyby nawet znalazł się jakiś drukarz skłonny opublikować księgę magiczną z pewnością nie uzyskałby na to zgody depozytariuszy tej wiedzy. Z pewnością zresztą istniały klątwy, które zagrażały tym, którzy odważyliby się ujawnić wiedzę tajemną czarnoksiężników (tak jak zagrażały tym, którzy chcieliby ujawnić tajemnice alchemiczne). Rękopiśmienna forma ksiąg magicznych musiała podkreślać ich tajemniczość, starożytność ich treści i ich samych. Wreszcie księgi te musiały być wykonane i poświęcone w pewien ściśle określony sposób (o czym również pisze Baschwitz), co wykluczało masową ich produkcję. 
Może natomiast dziwić brak druków ulotnych dotyczących procesów czarownic. Literaturą taką zaczytywano się na zachodzie Europy, np. w Anglii, gdzie publikowano wiele tego typu broszur. ${ }^{72}$ R. H. Robbins pisze, iż „W siedemnastowiecznej Anglii podobną rolę [kształtowania powszechnej opinii na temat czarów] odgrywały publikowane drukiem broszury zawierające teksty analogicznych wyznań [wymuszonych wyznań winy czarownic]. Przeciętni obywatele nie mieli z reguły dostępu do oryginalnych stenogramów zeznań przechowywanych w archiwach sądowych; ich wiedza na temat czarów brała się przede wszystkim z tego rodzaju druków ulotnych." "73 Brak takiej literatury dziwi tym bardziej, że, jak czytamy w przedmowie do Czarownicy powolanej (1639), ,....) temi czasy nasza Polska niezwyczainie zagęściła się nakształt pożarów czarownicami, lubo prawdziwymi, lubo mniemanemi: tak, isz na posiedzeniu i schadzkach zwyczaynych o żadney materyey więcey nie usłyszysz, jako o czarownicach (...)". Nawet jeżeli jest to opinia nieco przesadzona, to wydaje się niemożliwe, żeby nie publikowano w tym czasie popularnych druków dotyczących czarownic i procesów o czary. Dodajmy, że egzekucje były widowiskiem, które ściągało znaczną publiczność. Jak pisze B. Baranowski, w życiu polskiej wsi i małego miasteczka w XVII i XVIII w. procesy czarownic odgrywały olbrzymią rolę. Wiadomość o osądzeniu czarownicy błyskawicznie rozchodziła się po całej okolicy. Na miejsce stracenia wspólniczki diabła ściągały tłumy, by wziąć udział w takim niecodziennym widowisku. Ludność z żywą radością reagowała na to, że jeszcze jedna pomocnica czarta, która sprowadzała nieurodzaj lub zarazę zginęła w płomieniach. ${ }^{74}$ Zatem zapewne przy takiej okazji można było zarobić na broszurach opowiadających o palonej czarownicy, jej zbrodniach, procesie itp.

W Polsce nie było rodzimej oryginalnej literatury dotyczącej czarostwa. Publikowano u nas z reguły tłumaczenia i wyciagi (St. Poklatecki, St. Ząmbkowic, Czarownica powolana...). ${ }^{75}$ Prace D. Wisnera (który być może był autorem także Czarownicy powolanej...) pozostawały pod wpływem J. J. Godelmana, profesora z Tybingi.

W Polsce nie publikowano również tej literatury, która ukazywała się na zachodzie Europy. ${ }^{76}$ Nie było np. polskich wydań De la demonomanie des sorcieres (1580) J. Bodina, Pandaemonium (1684) R. Boveta, pism magicznych G. Bruno, Disquisitionum magicarum M. Del Rio, traktatów J. Wiera. Co ciekawe, Corneliusa Agryppy wydano pisma o ustrzeżeniu się morowego powietrza oraz traktat $O$ ślachetności a zacności plci niewieściey..., nie drukowano natomiast Philosophia occulta (Kolonia 1531-1533) 
czy De incertitudine et vanitate scientiarum. Popyt na literaturę czarowniczą musiał być $\mathrm{w}$ jakiejś mierze zaspokajany importem ${ }^{77}$.

Podstawą prawną orzekania w procesach o czary były Artykuty Prawa Maydeburskiego. Zostały one wydane w Polsce przez Bartłomieja Groickiego po raz pierwszy w r. 1558 (później jeszcze 13 wydań w XVI i XVII w.). Drugim podstawowym dziełem dla sędziów sądzących czarownice (choć często z pewnością jedynym, a bez wątpienia najsłynniejszym po dziś dzień) był Mot na czarownice wydany w Krakowie przez Stanisława Ząmbkowica w 1614 r. Od roku 1669 ukazywały się różne Instrukcje rzymskie po polsku i po łacinie, dowodzące konieczności karania czarownic.

Pierwszy traktat próbujący brać w obronę kobiety oskarżone o czarownictwo, autorstwa Joannesa Kirsteina Cerasinusa, Enchiridion aliquot locorum communium..., ukazał się w Krakowie w 1556 r. (później jeszcze 6 wydań). Autor Czarownicy powolanej... (Daniel Wisner?), Poznań 1639, występował nie tyle przeciw procesom o czary, co raczej przeciw zbyt rażącym nadużyciom w postępowaniach sądowych. Wisner w Trac-. tatus Brevis De Extra Magis Lamiis..., Poznań 1639, wystapił już bardziej otwarcie przeciwko procesom o czary. Fryderyk Spee w swoim, przeznaczonym głównie dla prawników Cautio criminalis, Poznań 1645, stara się zwalczać przede wszystkim wykorzystywanie tortur w procesach czarownic. Ostro przeciwko procesom o czary wystapił Krzysztof Opaliński w swoich Satyrach, Poznań(?) 1650 i kolejne wydania.

Index librorum prohibitorum z 1604 r. wymienia wiele książek magicznych, alchemicznych i astrologicznych, których nie wolno było czytać.

Sebastyan Miczyński w prymitywnym, przesyconym nienawiścią antysemickim pisemku Zwierciadlo korony polskiey..., Kraków 1618, zarzuca Żydom między innymi uprawianie czarnej magii i kult Szatana.

Najwięcej materiału udało mi się zebrać w części poświęconej astrologii i wróżbiarstwu. Nie jest to niczym niespodziewanym, ponieważ kalendarze i prognostyki astrologiczne publikowane były corocznie, często nawet ten sam drukarz wydawał kilka prognostyków w jednym roku. Z tego obfitego materiału można było wyciągnąć ogólne wnioski na temat języka, miejsc wydania, dedykacji druków astrologicznych. Analiz takich, jak sądzę, nie można przeprowadzić dla innych dziedzin wiedzy tajemnej, ze względu na niewielką ilość znanych publikacji i ich wielką różnorodność (najbardziej chaotyczna jest niewątpliwie część dotycząca alchemii). Jedynym ogólnym wnioskiem, jaki można tu postawić jest to, że widocznie ani alchemia, ani demonologia, ani magia nie należały do zainteresowań wydawców książek. 
Najbardziej dynamiczna była produkcja druków astrologicznych. Produkowano je już od końca XV w., liczba ich wzrasta w ciagu wieku XVI, najwięcej zaś powstało w wieku XVII. Różnego rodzaju prognostyki astrologiczne publikowane były w dalszym ciagu w wieku XVIII. Autorami ich byli profesorowie Uniwersytetu Krakowskiego i Akademii Zamoyskiej (katedra astrologii na Uniwersytecie została zlikwidowana dopiero w trzeciej ćwierci XVIII w.). Mniej dynamicznie przedstawia się produkcja innych typów druków omawianych w tej pracy. Dzieła demonologiczne (w szerokim zakresie rozumienia tego słowa) pojawiają się dopiero w drugiej połowie XVI w. (1558 - Wizerunek... Reja, nie biorąc pod uwagę o rok wcześniejszej Komedii... Bielskiego, która, jak można sądzić, nie miała większego wpływu na kształtowanie powszechnych wyobrażeń piekielnych) i odtąd aż do końca wieku XVII publikowane były dość regularnie. W tym samym czasie (1556) ukazało się w Polsce pierwsze dzieło prawnicze traktujące między innymi o procesach o czary (Enchridion... Cerasinusa). Później w latach 50. XVI w. ukazał się jeszcze jeden druk dotyczący czarownic (nie licząc ukazujących się co kilka lat - bądź nawet kilka razy w jednym roku - opracowań prawniczych Groickiego), w latach sześćdziesiątych - jeden, po osiemnastoletniej przerwie, w latach 80. - dwa druki, i wreszcie jeden w roku 1595 . W wieku XVII cztery druki opublikowano w pierwszym dwudziestoleciu, później trzy (a w zasadzie dwa) druki znamy $z$ końca lat 30 , dwa $z$ lat 40 , jeden $\mathrm{z}$ roku 1650 , jeden z 1669 , jeden z roku 1670 , cztery z lat 80 . i jeden z roku 1693. Najpóźniej ukazał się pierwszy druk tyczący zagadnień alchemicznych (1563 - Examen... Feliksa Łazarowicza z Sierpca). W XVI w. w tej dziedzinie najpłodniejsze były lata 60. (w r. 1569 ukazały się dwa dzieła Paracelsusa) i 80., w których opublikowano siedem tomów Pymandra komentowanego przez Rosseliusa. W r. 1595 ukazał się Pogrom... Poklateckiego. W XVII w. w kilkuletnich odstępach, wynoszących od trzech (1695-1698) do 31 lat (1650-1681) opublikowano osiem tego typu druków.

Wyznanie drukarzy nie miało, jak się wydaje, większego znaczenia przy publikowaniu druków astrologicznych. Tłoczyli je zarówno drukarze katoliccy, jak i protestanccy. Można przypuszczać, iż decydujące znaczenie miała tutaj wysoka dochodowość tego typu produkcji. Podobnie jest w przypadku druków dotyczących czarostwa. Drukiem ukazywały się w większości rozprawy (prawnicze bądź teologiczne), których autorzy przedstawiali czary jako zbrodnię. Stanowisko takie było wspólne katolikom i protestantom. Natomiast w przypadku druków demonologicznych sprawa 
wyznawanej religii miała znaczenie decydujące. Postaci Szatana, Lucypera, demonów, motywy piekielne wykorzystywane były w polemikach religijnych do dyskredytowania przeciwników (jest to znaczna część druków z kategorii „demonologiczne”). Należy więc przypuszczać, iż drukarze katoliccy publikowali jedynie takie druki, w których to Luter, Zwingli i protestanccy ministrowie sq̨ uczniami i wysłannikami piekieł. Jedynym znanym mi drukiem, w którym to hierarchia katolicka umieszczona jest w piekle, jest Wizerınek... Reja, wydany przez Wirzbiętę (zarówno autor, jak i drukarz byli kalwinami).

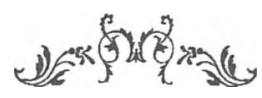

Przypisy:

'Artykuł ten jest skrótem pracy magisterskiej pt. Polskie druki z zakresu wiedzy tajemnej lat 1484-1699 i ich odbiór spoleczny napisanej w Instytucie Informacji Naukowej i Studiów Bibliologicznych pod kierownictwem prof. dra hab. Edwarda Potkowskiego w 1998 roku.

${ }^{2}$ R. Bugaj, Nauki tajemne w dawnej Polsce - Mistrz Twardowski, Wrocław 1986.

${ }^{3}$ J. Goliński, Okolice trwogi. Lęk w literaturze i kulturze dawnej Polski, Bydgoszcz 1997.

${ }^{4}$ J. Sokolski, Staropolskie zaświaty, Wroctaw 1991.

${ }^{5}$ B. Górska, Katalog kalendarzy XVII-XVIII w. w zbiorach Biblioteki Ossolineum, Wrocław 1968.

'K. Kłodzińska, Katalog kalendarzy od XVI do XVII w. w zbiorach Biblioteki Kórnickiej, Pamiętnik Biblioteki Kórnickiej, 8, 1963, s. 176-297.

${ }^{7}$ M. Paterak, Stare kalendarze i almanachy w zbiorach Biblioteki Muzeum Zamku w Eańcucie. Katalog, Łańcut 1978.

${ }^{8}$ J. Buła, Katalog kalendarzy polskich od XVI do XVIII wieku w zbiorach Biblioteki Czartoryskich, Kraków 1994.

${ }^{9}$ E. Steczek-Czerniawska, Kalendarze kaliskie. Bibliografia, Kalisz 1994.

${ }^{10}$ R. Bugaj, Nauki tajemne w dawnej Polsce - Mistrz Twardowski, Wrocław 1986, s. 79.

"W. Hubicki, Z dziejów chemii i alchemii, Warszawa 1991, s. 169.

${ }^{12}$ W. Hubicki twierdzi, że na dhugo zahamowała ona rozwój chemii.

${ }^{13}$ H. Barycz, Polacy na studiach w Rzymie w epoce Odrodzenia (1440-1600), Kraków 1938 , s. 36n.

14 Martin Steinpeiss, Liber de Modo Studendi seu Legendii Medicina, Wiedeń 1517. Wymienia on konieczną lekturę do studiowania na poszczególnych latach studiów, podaje też wskazówki, co i jak powinien czytać doktor medycyny, a nawet profesor. Wśród tych zalecanych książek znajdują się traktaty alchemiczne przypisywane Arnoldowi de Villanova, które od 1504 r. - o ile nie wcześniej - ukazywały się drukiem i wraz z jego traktatami medycznymi tworzyły tzw. Opera omnia. Dzieło to posiadal $\mathbf{m}$. in. Maciej z Miechowa. (W. Hubicki, op. cit., s. 176-177; L Hajdukiewicz, Biblioteka Macieja z Miechowa, Wrocław 1960, s. 323.) 
${ }^{15}$ Feliks Łazarowicz z Sierpca, Examen Thematvm D. Stanislai Zavacii Pici Cracovii Anno domini M.D.LXII, Cracoviae M.D.LXIII; Stanisław Zawadzki, Conclusiones seu theoreses..., Cracoviae 1563.

${ }^{16}$ W. Hubicki, op. cit., s. 37.

${ }^{17}$ Ibid., s. 38.

${ }^{18}$ Ibid., s. 169; R. Bugaj, Nauki tajemne $w$ dawnej Polsce, Wrocław 1986, s. 81-82.

${ }^{19}$ W. Hubicki, op. cit. s. 253.

${ }^{20}$ A także o tym, jak liczono się z bullą Jana XXII.

${ }^{21}$ Por. W. Hubicki, op. cit., s. 25; J. Kuchta, Nauki tajemne w Polsce w XV i XVI w. [w:] Lud 1928, s. 90.

22 Jan Musceniusz, Kalendarz świąt dorocznych..., Kraków 1569.

${ }^{23}$ W. Hubicki, op. cit., s 177.

${ }^{24}$ Paracelsus, Archidoxae..., Cracoviae [1569].

${ }^{25} \mathrm{~J}$. Kuchta, op. cit., s. 90.

${ }^{26}$ M. Eliade, op. cit., s. $14 \mathrm{I}$.

${ }^{27} \mathrm{~J}$. Tazbir, Bracia polscy na wygnaniu:studia $z$ dziejów emigracji ariańskiej, Warszawa 1977, s. 70-71 pisze o drukarni polskiej w Amsterdamie, prowadzonej przez arian.

${ }^{28} \mathrm{O}$ katedrze astrologii na Uniwersytecie Krakowskim na podstawie: K. Morawski, Historya Uniwersytetu Jagiellońskiego. Wieki średnie i Odrodzenie, Kraków 1900; M. Markowski, Stopniowa przewaga astrologii nad astronomia [w:] Historia astronomii w Polsce, Wrocław 1975, t. 1; tenże, Charakterystyka polskiego pismiennictwa astrologicznego epoki przedkopernikańskiej [w:] Odrodzenie i Reformacja w Polsce, 1991, t. XXXVI.

${ }^{29}$ M. Markowski, Stopniowa przewaga astrologii nad astronomia..., s. 170.

${ }^{30}$ A. C. Crombie, Nauka średniowieczna i początki nauki nowożyinej, Warszawa 1960 , t. 2, s. 135 .

${ }^{31}$ M. Markowski, ibid., s. 172.

${ }^{32}$ Na podstawie: M. Markowski, ibid., s. 174-178.

${ }^{33}$ W. Hubicki, Z dziejów chemii i alchemii, Warszawa 1991, s. 39.

${ }^{34}$ Dokumenty dotyczące tej sprawy opublikował T. Wierzbowski, Materialy do dziejów piśmiennictwa polskiego i biografii pisarzów polskich, tom Il, Warszawa 1904, s. 3-5, dokumenty nr 7,8 i 9.

${ }^{35}$ Był nim najpraw dopodobniej Wojciech Grabowski z Sierpca. Por. E Potkowski, Wojciech Grabowski z Sierpca i jego kalendarz astrologiczny (,Iudicium Astrologicum") na rok 1539 [w:] Notatki Plockie nr 2 (131), 1987, s. 9.

${ }^{36}$ Zob. Wierzbowski, op. cit., dokument 9.

${ }^{37}$ Kalendarz liturgiczny.

${ }^{38}$ M. Juda, Przywileje drukarskie w Polsce, Lublin 1992, s. 130.

39 J. Ptaśnik, Cracovia impressorum XV et XVI saeculorum, Loepoli 1922, s. 156; s. 170 nr 428.

${ }^{40}$ Co ciekawe, Monitor nr 1 z 1768 r. podaje również liczbę 20000 egzemplarzy drukownych co roku kalendarzy dla wieku Oświecenia.

${ }^{4 I}$ W. Urban, Ceny ksiażek w Polsce XVI i XVII wieku, Biuletyn Biblioteki Jagiellońskiej R. XLVI 1996, s. 61.

${ }^{42}$ W. Urban, op. cit, s.62; W. Adamczyk, Ceny w Warszawie w XVI i XVII wieku, Lwów 1938, s. 65; Tenże, Ceny w Lublinie od XVI do końca XVIII wieku, Lwów 1935, s. 49; St. Hoszowski, Ceny we Lwowie w XVI i XVII wieku, Lwów 1928, s. 53. 
${ }^{43}$ J. Ptaśnik, op. cit., s. 155; s. 114 nr 274; M. Juda, op. cit., s. 129.

${ }^{4}$ M. Wojciechowska, Z dziejów ksiaziki w Poznaniu w XVI wieku, Poznań 1927, s. 4142.

${ }^{45}$ M. Juda, op. cit., s. 142.

${ }^{46} \mathrm{~W}$ tabelach uwzględniam tylko drugą połowę XVI w. Pierwsza została omówiona w pracy magisterskiej D. Głowackiej powstałej w Instytucie Bibliotekoznawstwa i Informacji Naukowej w 1989 r. pod kierownictwem docenta doktora habilitowanego Edwarda Potkowskiego (maszynopis) i nie jest tu omawiana.

${ }^{47}$ J. Ptaśnik, op. cit., s. 152-153.

48. Zdarzało się jednak astrologom błędnie odczytać przyszłe wydarzenia z gwiazd: „W miesiacu maju [1508], wbrew zapowiedziom astrologa, w Krakowie i w innych miejscowościach zaczęla szaleć zaraza, która srożyła się aż do grudnia. Zginęlo od niej wielu mieszkańców Krakowa." L. J. Decjusz, Ksiega o czasach króla Zygmunta, Warszawa 1960, s. 31.

${ }^{49}$ W. Korotaj, Cenzura [w:] Slownik literatury staropolskiej, Wrocław 1990, s. 109.

${ }^{50}$ P. Buchwald-Pelcowa, Cenzura w dawnej Polsce..., Warszawa 1997, s. 150.

${ }^{51}$ J. Kuchta, Nauki tajemne w Polsce w XV i XVI w. [w:] Lud 1928, s. 84.

${ }^{52}$ E. Potkowski, Wojciech Grabowski z Sierpca i jego kalendarz astrologiczny (, Iudicium Astrologicum") na rok 1539 [w:] Notatki Plockie nr 2 (131)/1987, s. 7-11.

${ }^{53}$ Wyłączając druki wynotowane przez D. Głowacką (por. przypis 42).

${ }^{34}$ J. Delumeau, Strach w kulturze Zachodu, Warszawa 1986.

${ }^{55}$ M. Rożek, Diabel w kulturze polskiej, Warszawa 1993, s. 117.

${ }^{56}$ Por. np. J. Ch. Pasek, Pamięmiki, s. 17, 40.

${ }^{57}$ Por. J. Goliński, Okolice trwogi. Lęk w literaturze i kulturze dawnej Polski, Bydgoszcz 1997, s. 240. Zob. też: S. Radoń, Z dziejów polemiki antyariańskiej w Polsce XVI-XVII wieku, Kraków 1993, rozdz. Inwektywa w polemice religijnej przetomu XVIXXII wieku, s. $91-111$.

${ }^{58}$ J. Strzelczyk, Granice wyobraźni na wschodzie [w:] Wyobraźnia średniowieczna pod red. T. Michałowskiej, Warszawa 1996.

${ }^{54}$ J. Tazbir, Procesy o czary [w:] Odrodzenie i Reformacja w Polsce, XXIII, 1978, s. 163.

${ }^{60}$ Taki drugoplanowe postaci diabłów występują na przykład w Straszliwym widzeniu Piotra Pęgowskiego z Mazosz..., pochodzącym z ok. 1608 r. (zob. Straszliwe widzenie Piotra Pęgowskiego, opracował J. Sokolski, Wrocław 1998.)

${ }^{61}$ J. Sokolski, Staropolskie zaświaty, Wrocław 1991, s. 180.

${ }^{62}$ M. Rożek, op. cit., s. 143.

${ }_{63}$ J. Tazbir, op. cit., s. 158. Trudno natomiast zgodzić się z twierdzeniem prof. Tazbira, iż literatura demonologiczna w XVI w. dostępna była jedynie po lacinie. Teza taka może być słuszna jedynie w odniesieniu do pierwszej połowy tego stulecia, gdyż w r. 1570 ukazał się Postępek prawa czartowskiego..., w r. 1579 Żywoty świętych... Piotra Skargi, a w r. 1585 Wizerunek... Mikołaja Reja, które zawierały wiele fragmentów dotyczących demonologii.

${ }^{4}$ S. Bylina, Magia, czary i kultura ludowa w Polsce $w$ XV i XVI w. [w:] Odrodzenie i Reformacja w Polsce, t. XXXV, 1990, s. 42. Jak już napisałem wyżej, twierdzenie o nikłej znajomości literatury demonologicznej w Polsce trudno jest obronić dla drugiej połowy XVI w.

${ }^{65}$ B. Baranowski, Procesy czarownic w Polsce w XVII i XVIII wieku, s. 155-159. 
$\overline{{ }^{6}}$ Por. K. Zawadzki, Gazety ulotne polskie i Polski dotyczace XVI-XVIII w., Wstęp, s. X.

${ }^{67}$ J. Tuwim, Czary i czarty polskie oraz wypisy czarnoksięskie, Warszawa 1924, s. 211.

${ }^{6}$ A. Brückner, Encyklopedia staropolska, t. 1, szp. 192.

${ }^{69} \mathrm{~S}$. Bylina, Magia, czary i kuliura ludowa w Polsce XV i XVI w. [w:] Odrodzenie i Reformacja w Polsce, t. XXXV, 1990, s. 49.

${ }^{70}$ B. Cellini, Żywot spisany przez niego samego, Warszawa 1949, s. 102.

${ }^{7} \mathrm{O}$ księgach magicznych na podstawie: K. Baschwitz, Czarownice. Dzieje procesów o czary, Warszawa 1971.

${ }^{72}$ R. H. Robbins, Encyklopedia czarów i demonologii, Warszawa 1998, ss. 18, 52, 54, $55,120$.

${ }^{73}$ Ibid., S. 114. Broszury takie bywały dość obszerne. Na przykład The Wonderful Discovery of the Witches in the Country of Lancaster (London 1613) liczyło sobie 166 stron. Ibid., s. 176.

${ }^{74}$ B. Baranowski, Procesy czarownic w Polsce w XVII i XVIII wieku, Lódź 1952, s. 33.

${ }^{75}$ A. Brückner, op. cit., szp. 193.

${ }^{76}$ Dotyczy to zreszta nie tylko ksiag magicznych, ale także alchemicznych i demonologicznych.

${ }^{77}$ Podkreślmy - mowa tu wyłącznie o zbiorach zaklęć, kompendiach magii. Nie odnosi się to do ksiag magicznych, które same były przedmiotami magicznymi i które należało wykonywać w pewien szczególny, rytualny sposób. 